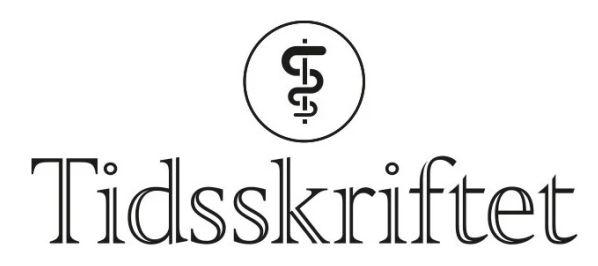

DEN NORSKE LEGEFORENING

\title{
A. Eskild og medarbeiderne svarer
}

\author{
KOMMENTAR \\ ANNE ESKILD \\ Anne Eskild er ph.d., spesialist i fødselshjelp og kvinnesykdommer, overlege og avdelingsleder ved \\ Kvinneklinikken ved Akershus universitetssykehus og professor ved Universitetet i Oslo. \\ Forfatteren har fylt ut ICMJE-skjemaet og oppgir ingen interessekonflikter.
}

IRENE SKAU

CAMILLA HAAVALDSEN

\section{JOSTEIN GRYTTEN}

Jostein Grytten er professor ved Institutt for samfunnsodontologi, Universitetet i Oslo og forsker ved Kvinneklinikken, Akershus universitetssykehus.

Forfatteren har fylt ut ICMJE-skjemaet og oppgir ingen interessekonflikter.

Takk til Hilde Engjom for kommentaren til våre studier av hvilken betydning medisinsk teknologi har hatt for perinatal dødelighet. Engjom spør om aborter av fostre med misdanninger, eller analyser av data fra svangerskap med fostremisdanning kan ha påvirket våre resultater. Det er lite trolig. Barn med en registrert misdanning var med i dataanalysene, men utgjorde bare en liten andel av alle barn som døde i perinatalperioden. De fleste barn med misdanninger overlevde.

De to første studiene vi gjorde, omfattet alle fødslene i Norge i perioden 1967-1995. Før 1999 ble ikke aborter på grunn av fostermisdanning registret i Medisinsk fødselsregister, og vi vet derfor ikke hvor mange slike aborter som fant sted i perioden. Men i toårsperioden 1996 - 97 var det 80 årlige aborter på grunn av fostermisdanning (11). En økning fra null i 1967. De fleste av fostrene i denne studien hadde ikke en misdanning som med stor sannsynlighet ville medført perinatal død om svangerskapet hadde vart lenger. Abort av misdannede fostre kan derfor antakelig ikke forklare våre resultater. Vi har også justert analysene for sykehusspesifikke trender, en justering for underliggende forandringer $\mathrm{i}$ observasjonsårene. Den siste studien vi gjorde, var om effekten av Doppler ultralyd, og omfattet fødslene i perioden 1995 - 2014. Doppler ultralyd brukes stort sett i siste halvdel av svangerskapet for diagnostikk av føtomaternelle sirkulasjonsforstyrrelser og vil nok ikke påvirke forekomsten av provoserte aborter. 
1. Eskild A, Nesheim BI, Berglund T et al. Svangerskapsavbrudd på grunn av fosterskade i Norge, 199697. Tidsskr Nor Lægeforen 2000; 120: 1000-3. [PubMed]

Publisert: 6. september 2021. Tidsskr Nor Legeforen. DOI: 10.4045/tidsskr.21.0584

(C) Tidsskrift for Den norske legeforening 2023. Lastet ned fra tidsskriftet.no 26. april 2023. 